\title{
PRIMARY PITUITARY ABSCESS
}

\section{Case report}

\author{
Ricardo Alexandre Hanel', Andrei Koerbel'2, Daniel Monte-Serrat Prevedello², \\ Marlus Sydnei Moro', João Cândido Araújo ${ }^{3}$
}

\begin{abstract}
Pituitary abscesses are potentially life-threatening lesions if not appropriately diagnosed and treated. The authors have operated on more than five hundred cases of pituitary tumors and only one represented a case of pituitary abscess. A 35-year-old woman was investigated for chronic frontal headache. CT scan showed a cystic sellar lesion with ring enhancement after contrast injection leading to an initial diagnosis of pituitary adenoma. She underwent a sublabial transsphenoidal approach to the pituitary gland. After dural opening, purulent material was obtained and no tumor or other associated lesion was detected. There was no evidence of current or previous septicemic illness, meningitis, cavernous sinus thrombosis or sinus infection. Cultures were negative. She was put on antibiotics and discharged after 4 weeks. Nowadays, 10 years after treatment, she is doing well, with no anterior pituitary hormone deficit. MRI shows a partially empty sella without residual lesion and the pituitary stalck is in the midline. The early diagnosis and adequate treatment of this life-threatening lesion may result in excellent prognosis.
\end{abstract}

KEY WORDS: abscess, pituitary gland, hypophysis.

\begin{abstract}
Abscesso primário de hipófise: relato de caso
RESUMO - Abscessos pituitários são lesões potencialmente graves se não diagnosticadas e tratadas de maneira apropriada. Os autores têm mais de 500 casos de tumores pituitários operados e apenas um único caso de abscesso pituitário. Uma mulher de 35 anos foi investigada por cefaléia frontal crônica. A tomografia computadorizada de crânio mostrou uma lesão selar cística com captação de contraste levando à hipótese diagnóstica inicial de adenoma hipofisário. A paciente foi submetida a um acesso sublabial transesfenoidal para a hipófise. Após abertura dural, foi encontrado material purulento sem sinal de tumor ou outra lesão associada. Não havia evidência de doença séptica prévia ou atual, meningite, trombose de seio cavernoso ou sinusite. Culturas foram negativas. A paciente foi submetida a tratamento com antibióticos e recebeu alta após 4 semanas. Atualmente, após 10 anos do tratamento, encontra-se sem déficit hormonal hipofisário anterior. Sua ressonância magnética de crânio mostra uma sela parcialmente vazia sem lesão residual, com o talo hipofisário na linha média. 0 diagnóstico e tratamento adequado desta lesão potencialmente grave pode resultar em excelente prognóstico.
\end{abstract}

PALAVRAS-CHAVE: abscesso, glândula pituitária, hipófise.

Pituitary abscess is a rare but potentially life threatening condition if not adequately diagnosed and treated. Since the first description by Simmonds in $1914^{1}$, only 121 cases have been reported in the literature ${ }^{2}$. Pituitary abscess implies pituitary gland involvement by an infectious process within the sella turcica characterized by the presence of an acute or chronic inflammatory reaction. This process may derive from a localized or generalized infection source (meningitis, sepsis), facilitated or not by a previous existing sellar lesion as adenoma, craniopharyngioma or Rathke's cleft cyst. Neither a definite infection origin nor associated conditions were apparent in half of cases reviewed by Lindholm et al. ${ }^{3}$.

We report on a patient who had a primary pituitary abscess, who survived with virtually intact anterior pituitary function. Important features to early diagnosis and fast recovery are discussed.

Department of Neurosurgery, Hospital Nossa Senhora das Graças, Curitiba PR, Brazil: 'Neurosurgeon; ${ }^{2}$ Resident in Neurosurgery; ${ }^{3}$ Neurosurgeon Coordinator of the Residency Program.

Received 2 January 2002, receive in final form 8 April 2002. Accepted 19 April 2002.

Dr. Daniel Monte-Serrat Prevedello - Rua Alcides Munhoz 433 - 80810-040 Curitiba PR - Brazil - FAX: 554150191. E-mail: prevedello@hotmail.com 


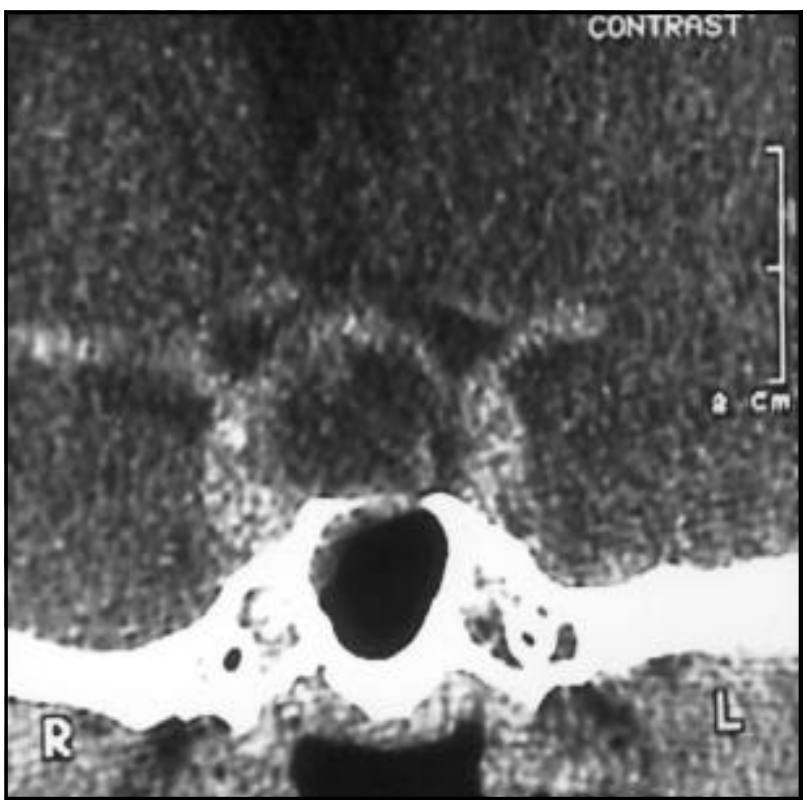

Fig 1. CT scan $2 \mathrm{~mm}$ thick section after intravenous contrast injection. Space-occupying lesion in the sella turcica with a suprasellar extension and destruction of the sellar floor. Note the presence of hypodensity at the center of lesion with a contrast-enhanced outline, filling up the sphenoidal sinus.

\section{CASE}

A 35-year-old woman, 6 months postpartum, with normal delivery, presented with a two-month complaint of persistent retro-orbital headache. The patient had no other symptoms. She had no history of or current evidence for infection, sinusitis or meningitis. Her physical examination was unremarkable. Her ophthalmological and neurological examinations were normal. A CT scan of the pituitary region with $2 \mathrm{~mm}$ thick sections before and after contrast injection was performed (Fig 1). It revealed a sellar enlargement with erosion of the dorsum sella and sellar floor. An intrasellar expanding lesion with suprasellar extension to chiasmatic cistern was found. The lesion was heterogeneous with a hypodense center and a peripheral enhancement by contrast. The diagnosis of cystic pituitary macroadenoma was made.

At that time she was admitted to the hospital. Laboratory tests revealed leukocytosis $\left(16500 / \mathrm{mm}^{3}\right)$ with no other abnormalities. Endocrinological evaluation showed moderate increase in prolactin levels $(72 \mathrm{ng} / \mathrm{ml})$ with normal values for TSH, T3, T4, cortisol, FSH, LH and GH.

She was submitted to a sublabial transsphenoidal approach. Erosion of sellar floor was noted. After dural opening and gland penetration a thick, yellowish purulent fluid was obtained. After drainage, gland inspection did not reveal signs of neoplasia or other lesion.

Bacterioscopy revealed polymorphonucleated cells $(+++/ 4)$ but no germs. Aerobic and anaerobic cultures were negative. Histopathological examination of adjacent dura showed non-specific inflammatory reaction. The patient was treated with intravenous antibiotics (cefazolin $1 \mathrm{~g}$ q8h, amikacin $450 \mathrm{mg} \mathrm{q} 12 \mathrm{~h}$ and chloranphenicol $1.5 \mathrm{~g} \mathrm{q} 6 \mathrm{~h}$ ) for 4 weeks and oral antibiotic (cefadroxil $500 \mathrm{mg} \mathrm{q} 12 \mathrm{~h}$ ) for 1 month after discharge.

She developed diabetes insipidus at the third day after surgery, which was managed with intramuscular DDAVP $10 \mathrm{U}$ q6h, which was the drug available at that time. Thirty days after surgery, her prolactin level was still around $70 \mathrm{ng} / \mathrm{ml}$ and she was started on bromoergocriptine, $5 \mathrm{mg} /$ day. Sixty days after bromocriptine therapy introduction, prolactin level was $2 \mathrm{ng} / \mathrm{ml}$ and the drug was discontinued. Subsequent prolactin level measurements remained within normal limits.

A final MRI evaluation obtained 6 years after surgery showed a partially empty sella with a centrally located pitu-

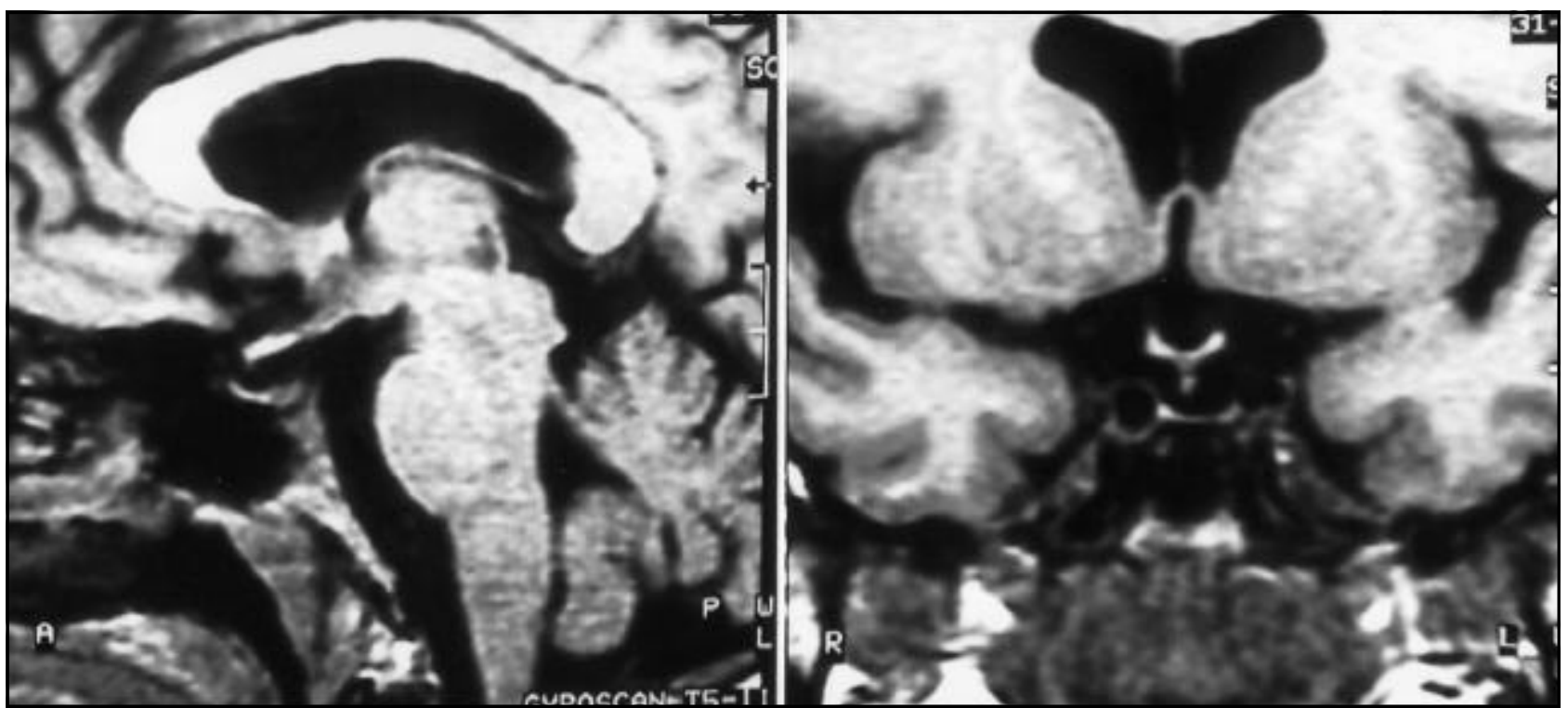

Fig 2. MRI T1-weighted midline sagittal section (A) and coronal section (B) 6 years after surgery showed a partially empty sella with a centrally located pituitary stalk, without evidence of tumor and/or collection. 
itary stalk (Fig 2). Nowadays, 10 years after treatment, the patient is doing well, on oral DDAVP $0.1 \mathrm{mg} \mathrm{q} 12 \mathrm{~h}$, with no other hormonal disturbance.

\section{DISCUSSION}

Pituitary abscess, as first described by Simmonds in $1914^{1}$, denotes involvement of the pituitary gland by an intrasellar infectious process ${ }^{4}$.

Pituitary abscess incidence is low and difficult to exactly estimate. In Cushing's classic series of pituitary tumors, there was no reference to abscess ${ }^{5}$. Jain et al. ${ }^{6}$ reported that pituitary abscesses constituted $0.6 \%$ of all pituitary lesions operated by them. Of 500 expansive pituitary lesions encountered by Scanarini et al. ${ }^{7}$ during a 27 -year period, only two were abscesses. This is the unique case in the authors' series of 503 transsphenoidal approaches to sellar lesions ( $0.2 \%)$.

There was a remarkable female predominance within cases of pituitary abscesses described by Wilson ${ }^{8}$. The same author recently reported 24 patients with pituitary abscess, including the seven cases reported previously, and only nine patients were female ${ }^{2}$.

According to etiology, three groups of pituitary abscesses may be distinguished. ${ }^{9}$ They may complicate preexisting growing lesions, usually adeno$\operatorname{mas}^{7,8,10}$. Pituitary abscess has also been reported complicating intrasellar craniopharyngiomas ${ }^{3,11}$ and Rathke's cleft cyst ${ }^{12-14}$. Tumors are possibly vulnerable to infection because of impaired circulation, areas of necrosis or local immunological impairment ${ }^{15}$. While such explanations remain speculative, pituitary abscesses are too frequently simultaneous with expanding sellar lesions to attribute this association to chance ${ }^{8}$. Kroppenstedt et al. ${ }^{16}$ documented changes in MRI imaging of a patient who developed an abscess within her preexisting sellar tumor just after a tooth extraction. Their finding also support the hypothesis that presence of tumor may determine changes in local control of infection, facilitating its occurrence.

In the absence of tumor, pituitary abscess may be the result of direct extension or hematogenous spreading of sphenoid sinusitis, meningitis, cavernous sinus thrombophlebitis or a contaminated cerebrospinal fluid (CSF) leakage ${ }^{4,17}$. When pituitary abscess does not coexists with meningitis or an adjacent sinus infection, it is difficult to determine the original site of infection 4 .

The incidence of intrasellar abscess is surprisingly low after transsphenoidal pituitary surgery. Only five cases of pituitary abscess had been reported in the English literature subsequent to surgery ${ }^{18}$ until the recent study of Vates at al. ${ }^{2}$ that report 10 out of 24 cases of pituitary abscess in patients who had undergone surgery for pituitary disorders. These abscesses may be due to intraoperative contamination $^{2,8,19}$ or due to CSF leakage (secondary abscesses) $)^{2,8}$.

The present case is included in a third group, in which a clearly identifiable source of infection is not obtained. Lindholm et al. ${ }^{3}$ did not identify infection origin or tumor coexistence in 9 out of 21 cases.

Domingue and Wilson ${ }^{8}$, reviewed 29 cases of pituitary abscesses and found 14 cases with negative cultures. Vates at al. ${ }^{2}$ reported 10 out of 24 cases whose cultures obtained during surgery were negative. Although some authors believe that a sterile abscess is not an abscess at all, but rather aseptic, liquefactive necrosis of infarcted pituitary gland or tumor, or the contents of an atypical pituitary cyst (for example, Rathke cyst or craniopharyngioma), we agree with the viewpoint of Vates at al. ${ }^{2}$ that an experienced surgeon easily distinguishes other lesions from pus and a sterile culture may result from an inadequate bacteriological technique or from antibiotic therapy initiated before or during surgery. When culture is positive the most commonly identified pathogens are Staphylococcus sp, Streptococcus sp, Neisseria sp, E. coli, Corynebacterium sp and dyfteroids $s^{2,3}$. Cases of mycotic abscesses have been reported due to Aspergillus ${ }^{20,21}$, Candida ${ }^{22}$, coccidiodomycosis ${ }^{23}$, histoplasmosis ${ }^{24}$ and blastomycosis ${ }^{25}$. In contrast to bacterial pituitary abscesses, most fungal infections are associated with some type of immunosuppressed patients ${ }^{18}$. Cases of parasitic pituitary infection have also been reported, including cysticercosis ${ }^{26}$ and echinococosis ${ }^{27}$. Güven et al. ${ }^{28}$ reported pituitary abscess secondary to brucellosis.

The predominant clinical features of pituitary abscesses resemble those of pituitary adenomas. Pituitary abscesses usually present either with endocrinologic disturbance (amenorrhea, polyuriapolidipsia, and susceptibility to cold) or with symptoms related to mass effect (headache, visual field defect). Headache without a specific pattern may be the only symptom and it was far and away the most common presenting complaint in a recent study ${ }^{2}$. Meningitic syndrome may be associated to pituitary mass effect signs ${ }^{29}$, in up to $90 \%$ of cases. ${ }^{8}$ Fever is present in $50 \%$ of $\operatorname{cases}^{30}$. Domingue and Wilson ${ }^{8}$ found 16 cases of visual field defect out of 29 patients reviewed. Vates et al. ${ }^{2}$ reported half of the 24 patients with visual disturbances. Pituitary 
apoplexy $^{31}$, sleep attacks ${ }^{32}$ and recurrent aseptic meningitis ${ }^{33}$ have been described as unusual presentation of pituitary abscess.

The present case is the second pituitary abscess in a postpartum woman in the literature, following the first description by Enzman and Sieling, in $1983^{34}$. This association should be further studied and might represent a predisposing factor to pituitary infection, presumably due to flow alteration within the gland during pregnancy.

Unfortunately no preoperative diagnostic maneuvers are specific for pituitary abscess. However, knowledge of several features can suggest its presence ${ }^{21}$. As previously mentioned, a past history of meningitis, sepsis and sinusitis may suggest the diagnosis ${ }^{8,21}$. Rapid neurological deterioration in a patient with sellar tumor after a presumed bacteremia should point to the possibility of abscess formation ${ }^{16}$.

CSF examination may be useful even with no signs of meningitic syndrome. It may reveal a slight pleocytosis, elevated protein content, or depressed glucose concentration, suggesting a parameningeal focus of inflammation ${ }^{4}$.

Conventional radiological investigation may reveal changes compatible with a sellar mass. In Lindholm et al. ${ }^{3}$ report, only three out 21 patients had a normal sella. Erosion and/or expansion were the most common sellar findings.

The advent of CT and more recently MRI added another dimension to sellar affections. CT scan findings, as first reported by Enzmann and Sieling ${ }^{34}$, often refers to an intrasellar lesion, eventually expanding to the suprasellar region and devoid of specificity ${ }^{35}$. The presence of hipodensity in the pituitary gland with enhancement of its outline by contrast injection and filling the sphenoid sinus with destruction of sellar floor are also non-specific ${ }^{9,34}$. Bossard et al..$^{30}$ consider the sellar floor destruction as a misleading sign, wrongly suggesting a downward extension of an invasive adenoma rather than upward propagation of sinus infection.

The use of MRI in a case of pituitary abscess was first described by Dickob et al. ${ }^{36}$. They reported a hypointense signal on T-1 weighted sequences and hyperintense signal on T-2, indicating a liquefied lesion, but also compatible with necrotic part of any adenoma. Despite CT and MRI use, the preoperative diagnosis of pituitary abscesses remains difficult. Bossard et al..$^{30}$ suggested two important signs that may lead to a correct diagnosis. The first sign involves disparity between the important sphenoid features (effusion within the sinus, wide sellar floor destruction) and relatively small volume of the pituitary lesion. The second sign is the enhancement of the sellar lesion outline by both CT and MRI contrast, with simultaneous extensions to the sphenoidal sinus. Wolansky et al. ${ }^{37}$ described a case of meningeal enhancement by contrast, with may be diagnostic when associated with a ring-enhancing pituitary mass.

Lymphocytic hypophysitis is characterized by infiltration of the anterior pituitary gland with lymphocytes and plasma cells and by fibrosis. Granulomatous hypophysitis is another inflammatory disorder of the pituitary gland and it is characterized by granulomas with epithelioid histiocytes and multinucleated giant cells but also shows lymphocytes. They may be difficult to differentiate preoperatively from other pituitary lesions as adenoma or even an abscess, because they also use to enhance. However, the consistency and appearance of a gland with hypophysitis during the surgical procedure are unique. They are whitish, greasy and firm without any sing of pus ${ }^{38}$.

The management of choice is surgical drainage by transsphenoidal approach followed by antibiotictherapy $2,8,9$. Other approaches may result in intracranial dissemination of infection. Regardless of the surgical approach used, the surgeon should be aware of the risk for postoperative meningitis, infectious vascular lesion and CSF fistula 4 .

Pre-CT scan era, Domingue and Wilson reviewed 29 patients, with $28 \%$ mortality, and this rate increased to $45 \%$ if meningitis was also present ${ }^{8}$. More recently, Boogan reported the prognosis of surgically treated patients as excellent, with $80 \%$ of visual function recovery, limited only by the severity and chronicity of preoperative damage $\mathrm{e}^{4}$.

In conclusion this case report supports the necessity of an early diagnosis, when the institution of adequate treatment may bring patients with this lifethreatening condition back to a normal life, with normal anterior pituitary function. Early diagnosis is difficult in cases of primary abscess. Additional clues to prompt pre operative diagnosis should be sought. Among these are leukocytosis and post partum period, as in the present case, in addition to image findings.

\section{REFERENCES}

1. Simmonds M. Zur Pathologie der Ag hypophysis. Verh Dtsch Pathol $1914 ; 17: 208-212$

2. Vates GE, Berger MS, Wilson CB. Diagnosis and management of pituitary abscess: a review of twenty-four cases. J Neurosurg 2001:95;233-241.

3. Lindholm J, Rasmussen P, Korsgaad O. Intrasselar or pituitary abscess. J Neurosurg 1973;38:616-619. 
4. Boggan JE. Pituitary abscess. In Wilkins RH, Rengachary SS (eds.) Neurosurgery 2.Ed, New York: McGraw-Hill, 1996: 3321-3322.

5. Cushing H. The pituitary body and its disorders. Philadelphia, Lippincott, 1912.

6. Jain KC, Varma A, Mahapatra AK. Pituitary abscess: a series of six cases. Br J Neurosurg 1997;11:139-143.

7. Scanarini M, Cervellini P, Rigobello L, Mingrino S. Pituitary abscesses: report of two cases and review of literature. Acta Neurochir 1980;51:209-217.

8. Domingue JN, Wilson CB. Pituitary abscesses: report of seven cases and review of literature. J Neurosurg 1977;46:601-608.

9. Fong TC, Johs RD, Long M, Myles ST. CT of pituitary abscess. AJR 1985;144:1141-1142.

10. Selosse P, Mahler C, Klaes RL. Pituitary abscess: case report. J Neurosurg 1980;53: 851-852.

11. Shanley DJ, Holmes SM. Salmonella typhi abscess in a craniopharyngioma: CT and MRI. Neuroradiology 1994;36:35-36.

12. Bognàr L, Szeifert GT, Fedorcsàk I, Pàsztor E. Abscess formation in Rathke's cleft cyst. Acta Neurochir (Wien) 1992;117:70-72.

13. Perun JG, Eiras J, Carcavilla LI. Abcès intrasellaire au sein dún kyste de la poche de Rathke. Neurochirurgie 1981;27:201-205.

14. Thomas N, Wittert GA, Scott G, Reilly PL. Infection of a Rathke's cleft cyst: a rare cause of pituitary abscess. Case illustration. J Neurosurg 1998;89:682.

15. Askenasy JM, Israeli J, Karny $\mathrm{H}$, et al. Intrasselar abscess simulating pitiutary adenoma. Neurochirurgica 1971;14:34-37.

16. KroppenstedtSN, Liebig T, Mueller W, Gräf KJ, Lanksch WR, Unterberg AW. Secondary abscess formation in pituitary adenoma after tooth extraction. J Neurosurg 2001;94:335-338.

17. Verdalle $\mathrm{P}$, Roquet $\mathrm{E}, \mathrm{Hor} \mathrm{F}$, et al. Pituitary abscess. A rare complication of sinusitis. Rev Laryngol Otol Rhinol (Bord) 1997;118:327-329.

18. VanGilder JC. Pituitary abscess. In Osenbach RK, Zeidman SM (eds.). Infections in neurological surgery: diagnosis and management. Philadelphia: Lippincott-Raven, 1999:119-122.

19. Henegar MM, Koby MB, Silbergeld DL, Rich KM, Moran CJ. Intraselar abscess following transsphenoidal surgery. Surg Neurol 1996;45:183-188.

20. Larrañaga J, Fandiño J, Gomez-Bueno J, Rodriguez D, Gonzalez-Carrero J, Botana C. Aspergillosis of the sphenoid sinus simulating a pituitary tumor. Neuroradiology 1989;31:362-363.

21. Ramos-Gabatin A, Jordan RM. Primary pituitary aspergillosis responding to transsphenoidal surgery and combined therapy with amphotericin -B and 5-fluorocytosine. J Neurosurg 1981;54:839-841.

22. Heary RF, Maniker AH, Wolansky LJ. Candidal pituitary abscess: case report. Neurosurgery 1995;36:1009-1012.

23. Scanarini M, Rotilio A, Rigobello L, Pomes A, Parenti A, Alessio L. Primary intrasellar coccidiodomycosis simulating a pituitary adenoma. Neurosurgery 1991;28:748-751.

24. Schultz DM. Histoplasmosis of the central nervous system. JAMA 1953;151:549-551.

25. Schwartz J, Baum GL. Blastomycosis. Am J Clin Pathol 1951;21:999-1029.

26. DelBrutto OH, Guevara J, Sotelo J. Intrasellar cysticercosis. J Neurosurg 1988;69:58-60

27. Ozgen T, Bertan V, Kansu T, Akaliu S. Intrasellar hydatid cyst: case report. J Neurosurg 1984;60:647-648.

28. Güven MB, Cirak B, Kutluhan A, Ugras S. Pituitary abscess secondary to neurobrucellosis. J Neurosurg 1999;90:1142.

29. Grosskopf D, Chamouard JM, Bosquet F, Billet R, Poisson M, Buge A . Abcès hypofisaire: etude d'un cas et revue de la littérature. Neurichirurgie 1987;33:228-231.

30. Bossard D, Himed A, Badet C e cols. MRI and CT in a case of pituitary abscess. J Neuroaldiol 1992;19:139-144.

31. Kingdon CC, Sidhu PS, Cohen J. Pituitary apoplexy secondary to an underlying abscess. J Infect 1996;33:53-55.

32. Donnet A, Trefouret S, Millet Y, Grisoli F. Pituitary abscess revealed by sleep attacks. Surg Neurol 1999;51:564-565.

33. Guillaume D, Stevenaert A, Grisar T, Doyer P, Reznik M. Pituitary abscess in recurrent aseptic meningitis. J Neurol Neurosurg Psychiatry 1990;53:925-926.

34. Enzmann DR, Sieling RJ. CT of pituitary abscess. AJNR 1983;4:79-80.

35. Blackett PR, Bailey JD, Hoffman HJ. A pituitary abscess simulating an intraselar tumor. Surg Neurol 1980;14:129-131.

36. Dickob M, Scharphuis T, Distelmaier P, Hoffman G. Die Diagnostik des Hypophysenabszesses mittels MRI und hochauflösender CT. Neurochirurgia 1989;32:184-186.

37. Wolansky LJ, Gallagher JD, Heary RF, et al. MRI of pituitary abscess: two cases and review of the literature. Neuroradiology 1997;39:499-503.

38. Honegger J, Fahlbusch R, Bornemann A, et al. Lymphocytic and granulomatous hypophysitis: experience with nine cases. Neurosurgery 1997;40:713-723. 